\title{
Supplemental Instruction as a Tool for Students' Academic Performance in Higher Education
}

\author{
Oyinlola Omolara Adebola
}

School of Social Sciences and Language Education, Faculty of Education, University of the Free State, South Africa Email: Adebolaoo@ufs.ac.za

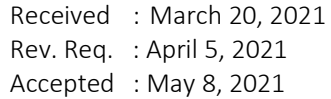

How to cite this paper: Adebola, O. O. (2021). Supplemental Instruction as a Tool for Students' Academic Performance in Higher Education. Journal of Culture and Values in Education, 4(2), 42-51. https://doi.org/10.46303/jcve.2021.4

This is an Open Access article distributed under the terms of the Creative Commons Attribution 4.0 International license (https://creativecommons.org/licenses/by/4.0/)

\begin{abstract}
Supplemental instruction (SI), which can be referred to as academic support has been linked to the successful academic performance of university students both locally and internationally. This study explores the successful implementation of $\mathrm{SI}$ to encourage students toward academic performance in a South African university. Constructivism theory (CT) was adopted as the theoretical framework for the study while Participatory Research (PR) was the research design. A focused group interview was used to collect data because of its relevance and assumptions of academic support such as supplemental instruction. Two lecturers, two tutors, two tutees, and two SI personnel were selected for the study from a selected university. At the same time, thematic analysis was chosen to analyse the data generated. The findings showed that through the intervention of SI, first-year students' academic performance increased while the dropout rate has also reduced.
\end{abstract}

Keywords: Supplemental instruction, students' academic performance, first-year students, higher education, constructivism

\section{Introduction}

Students' academic performance can be referred to as the overall knowledge gained from students through assessments such as tests and examination within a period of time by lecturers (Narad \& Abdullah, 2016). Academic performance enhancement through supplemental instruction has been said to increase student achievement globally and in local universities, including the university where this study was conducted (Adebola et al., 2020; Kapur, 2018; Malm et al., 2018). This means that the impacts of SI in academics cannot be neglected nor under-emphasised in academic performance. According to Wilmot and Telang (2017), there was an increase in students' academic performance of first-year students who attended supplemental instruction at a specific period compared with those who did not attend. 
This indicates that the rate at which students drop out of the university has reduced, increasing the graduation output.

First-year students encounter many challenges, such as lack of academic support and financial problem, and as such, they sometimes find it unnecessary to attend tutorial sessions (Fluke et al., 2014; Saleem et al., 2018). On the contrary, Yasin and Dzulkifli (2010) suggested that firstyear students need to socialise, as this would contribute to positive academic performance, boost communication skills, and help them better understand the environment. In support of the view above, first-year students are influenced mainly by their peers and the new academic environment and naturally do not want to attend academic support because they believe it is of no use. Therefore, the problem of the study is the uncared attitude of first-year students towards attending tutorial sessions (Saleem et al., 2018).

Academic support such as supplemental instruction has been proven to show that SI leads to an increase in students' academic performance, especially first-year students in universities, as revealed by Goomas (2014), Skoglund et al. (2018) and Omodan and Ige (2021). On the other hand, supplemental instruction is said to have promoted the active participation of students, increased collaborative learning spirit among students and served as a means of getting feedback from students (Adebola, 2020; Budiharso \& Tarman, 2020; Double et al., 2020; Sukrajh, 2018). According to these scholars, supplemental instruction has positive impacts on students apart from academic performance achievement. Students involvement in class discussion is crucial as it motivates both the tutor and tutees during tutorial sessions. Subsequently, feedback is another benefit that is associated with supplemental instruction through tutorial sessions.

\section{Research question}

Can supplemental instruction contribute to the academic performance of first-year university students?

\section{Research objectives}

This study aims to examine the successful implementation of supplemental instruction on the academic performance of first-year students in universities.

\section{Methodology Research design}

This study adopted participatory research (PR) due to its relevance and features in conducting research. PR is an approach that appreciates the coming together of those concerned in providing solutions to their problems. This means allowing the disadvantaged or marginalised, who are the students, to be part of the investigation process of finding a solution to their problem. This opportunity gives the students a sense of belonging by allowing them to make their voices heard through the project. PR believes that both the process and how research is done is as important as the results (Bergold \& Thomas, 2012). Participatory research supports participants' thinking and allows them to be free and treated equally without bias. This study attests that the implementation of SI led to the improved academic performance of first-year 
students in the university where the study was conducted, and PR is relevant and appropriate. Therefore, PR, which by its nature privileges the marginalised to make their voices heard, will permit concerned students, the students who were offered modules and participants to tell their stories regarding problems facing supplemental instruction and suggest the way forward.

\section{Participants}

The selection consists of eight participants, of which two were lecturers of the university, two tutors who facilitate the first-year students, two tutees who are the students, and two SI coordinators who deal with the administrative aspect. The study targeted university lecturers, students at first-year who attended tutorial sessions, and second-year students who were tutors at the Centre for Teaching and Learning (CTL). These participants were chosen based on their expertise and involvement as it could help the study. The study adopted purposive sampling techniques in selecting its participants because of the relevance.

\section{Presentation of Data and Discussion}

For anonymity sake, the participants in the study were represented using A1 \& A2 (Lecturers), B1 \& B2 (Tutees), C1 \& C2 (Tutors), and D1 \& D2 (SI Leaders/Personnel). The study is qualitative research and interview was used to collect data. This instrument was chosen because the researcher needed some in-depth information regarding the supplemental instruction as academic support from the targeted participants. This information helped the researcher decide and design the appropriate questions held with participants through a face-to-face interview. According to Ryan, Coughlan and Cronin (2009), an interview is defined as that type of data collection that is used to get in-depth information regarding an opinion, thought or phenomenon.

\section{Data collection}

The study adopted an interview instrument to collect data; this was done such that the researcher had a face-to-face interview with the students together and lecturers individually. Since the researcher already prepared an open-ended question to ask each participant, the process of interviewing them was easy to administer. Meanwhile, each of the questions drafted and asked was informed by the research questions. Questions such as "Does SI enhance firstyear students' academic performance?" among others, were asked. The researcher spent at least 10-15minutes with each participant while the interview was being recorded on a video recorder and later transcribed and coded. An unstructured interview was used to collect data for the study. An unstructured interview is an open interview that allows the interviewer to ask specific questions on the research topic (Dana, Dawes \& Peterson, 2013). This means that both interviewer and interviewees can have an informal conversation without following a specific regulation. Meanwhile, Dana (2013) argued that an unstructured interview is a valuable tool to reveal crucial information regarding a specific topic, especially when there are laid-down rules. This method allows transparent conversation as both parties reflect on real-life scenarios. An unstructured interview is relevant to this study as it allows participants to voice their opinions without fear. It also allows participants to be part of a system where knowledge is constructed. 


\section{Data Analysis and Ethical Consideration}

According to Braun and Clarke (2006), the thematic analysis (TA) is a qualitative method of data analysis for identifying, analysing, organising, describing, and reporting themes that originate within a set of data. This means that TA is theorised as a systematic form of data analysis classified and organised so that the pattern of meaning is critically examined. By so doing, data is broken into themes in other to make sense with regard to thematic prearrangement. TA as a method of data analysis allows the researcher to analyse the data according to the themes and subthemes (Holloway \& Todres, 2003). The relevance of thematic analysis to the study are many and includes what Jugder (2016) said that data generated through interview are effectively simple and meant to be rationalised. Because of its flexibility, TA assists researchers in analysing data based on themes and subthemes. The thematic analysis allowed the researcher to analyse the interview from a perspective point of view. In this study, data were analysed by the categorisation of themes; that is, after the data had been transcribed, the researcher categorised the common themes, ideas, and pattern to their meanings as examined. After a critical study of the categorisation of themes, the researcher coded each group, searched for patterns, named the themes, and finally report the outcomes.

The study was approved by the ethical committee of the University of the Free State with approval number UFS-HSD2018/1132. Participants' consent was sought, and they were assured that their information and utterances would be kept confidential from third parties during and after the study. They were assured of anonymity and that their utterances would remain anonymous.

\section{Results and Discussion}

Under this heading, two areas of success: increase in students' achievement output and reduction of dropout rate (retention rate) have been pointed out as evidence of academic success when SI is implemented in higher institutions of learning (Muray, 2014). The data was gathered using the objective of the study, "Possible successes from the implementation of supplemental instruction in the university", while two themes such as increment in students' achievement and reduction of the dropout rate of first-year students will be discussed. See the table below.

\begin{tabular}{lll}
\hline Objective & \multicolumn{2}{l}{ Analysis of subthemes } \\
\hline To provide evidence of & $\bullet$ & Increment in students' achievement (outputs) \\
success where SI is best & $\bullet$ Reduction of dropout rate (retention rate) \\
practised. & & \\
\hline
\end{tabular}

\section{Increment in Students' Achievement (Output)}

The findings revealed that supplemental instruction increases first-year students' achievement and students in general. An increment in students' achievement is one of the tremendous success that has been recorded in students' academic performance using SI. Apart from academic performance, students have developed social relationship skills and improved communication among themselves. Increment in students' achievement in the university has proven to be successful in academic performance and in terms of their level of social interaction 
due to SI. Supplemental instruction had shown extensive evidence of success of first-year students in academic performance (Bertolini, Stmmel \& Thorngren, 2016).

Participant C1: As a student, I think attending tutorials enhanced my academic performance. Instead of being an average student, I became a top student. Again, your focus and drive are improved because you can see the seriousness on this academic space. It improves and enhances academic performance.

The above participant, who was also a university student, attested that attending tutorials has made her one of the top students in her academic performance. This attests to her statement that, indeed, SI through tutorial sessions enhances students' academic performance, especially first-year students. She went further to say that as a student (tutee), attending tutorials had benefited her a lot. She said that some of the difficulties she encountered during lectures concerning content knowledge were solved in tutorials with the help of tutors. No wonder Cunningham (2012) testified that SI enhances students' academic performance.

Participant C2: As a previous tutee, I have seen that tutorials help a lot because some of the things you won't grasp during lectures, you get a clear picture of the content and clear understanding when you go to tutorials.

Participant A2: Having a prior discussion with the tutors, what I have realised is that as a lecturer, I would first address more than 200 students regarding what I was teaching, but with the tutoring programme, the students say that the tutors explained things better. As a lecturer, I thought that I had explained my topics very well; meanwhile, I find that the tutors' explanations were surely reaching the students.

Another participant, a lecturer, talked about SI from a different perspective. He acknowledged that being a lecturer with a large class, it might not be easy to reach students' expectations. He said that having a prior discussion with tutors on what he was teaching in terms of content knowledge helps greatly. This argument is supported by Mbah (2015) that prior knowledge enhances students' academic performance. It is assumed that, sometimes, tutors may explain things more clearly and simply to students than lecturers, as testified by participant A2. From these statements, the participants also stated that the tutees who attended tutorials stated that tutors often explained concepts better, give relevant examples and have context knowledge than the lecturers. All these point to the fact that SI enhances students' academic performance and increases the number of graduates each year. This was supported by another participant (lecturer) who proposed that students end up with high marks after attending tutorials, unlike the lecturer who may might be too harsh on them due to the stress of work overload. From her statement, it is believed that through the tutorial programme, there had been a huge difference in students' academic performance such that most students have achieved and surpassed the average percentage as agreed upon by Széll (2013) and Hermann (2010).

It is safe to say that SI growth has led to an increment in the achievement output and empowerment of tutors with managerial skills for their students during tutorials. They have learnt to respect one another, be creative on their own, design charts, record their activities, 
post them on a blackboard and expose them to workplace ethics, which will help them relate better with people after studying in the university. Furthermore, the pass rate of students attending $\mathrm{SI}$ has been satisfactory. This is according to another participant, who does not see SI as just a programme, but as a system that has proven that students who attend tutorials with seriousness and focus can come out in flying colours.

Participant A1: For me, the part of the growth was also on the tutors who went through the programme. This has also enabled them to manage their groups and let them have that work ethic to understand that they need to respect time, their classes, and be creative.

Participant A2: The pass rate indicates the return on investment (ROI) to the country-it means that the Department of Education has invested money to its citizens (students), and when they pass, they will not be a burden to the government. They can cater for themselves (sustainability).

In another perspective, participant $\mathrm{A} 2$ believes $\mathrm{SI}$ has contributed to the increase in the "Return on Investment" (ROI) of the country. This means that since the South African government, through the Department of Education, is funding (FUNZA, NSFAS) some education students in university, it makes it easy for them to focus on their studies and payback upon completing their studies. This process has led to tremendous growth in the country's investment because the kind of funds they receive compels the government to place them in schools as soon as possible (Kopish \& Marques, 2020). This implies that when they start working, they are not a burden to the government anymore, and at the same time, they start to earn salaries, taking care of themselves and their immediate families.

Participant A2: I think in terms of pass rate, it has been satisfactory. Part of not having high marks may be that as lecturers who handle the first year up to the fourth year and honours students, I suspect we were too harsh on them as first-year students, expecting them to perform at a level higher than theirs as well. This could be one weakness on our part as lecturers. However, in terms of the satisfactory performance of students, I think a number of them have reached the average pass percentage. With $\mathrm{SI}$, most of them could design their charts and record their role-play. I would say it is a success.

Another point raised aside from the increase in the pass rate is the workload of each lecturer in the faculty. This is to say that lecturers have to teach first-year to final year students and postgraduate students, which sometimes inhibits them from giving their best. He believed that students could have performed beyond satisfactory to maybe excellent level. However, with the intervention of $\mathrm{SI}$, students who attend tutorial sessions perform well and their creative skills have also been enhanced such that they can design charts, record their work and send it on the blackboard for their tutees. Despite all the challenges encountered by lecturers, SI personnel and students, participant A1 said categorically that students' pass rate in the university since the intervention of SI is worth applauding. 


\section{Reduction of students' dropout rate}

Supplemental instruction, a type of academic support in universities, has been associated with students' success at universities, most significantly, first-year students. Retention rate, which is also known as reduction of dropout rate in this study, refers to the increase in the number of students who decided to continue with their studies after receiving tutorial sessions (Moodley \& Singh, 2013).

The findings revealed that supplemental instruction intervention has reduced the dropout rate of first-year students and indirectly increased the retention rate. First-year students who wished to drop out of the university due to their inability to cope academically were rescued through tutorial sessions. However, tutorial sessions were held by senior students (4 ${ }^{\text {th }}$ year) who divided students into smaller groups to explain the subject concept taught in the large classroom by the lecturer to tutees first-year in a simpler way. Furthermore, Manalo et al. (2010) mentioned that even though there are so many factors responsible for students' retention in university, the tutorial session is one way students are retained in the university, thereby leading to a reduction of students' dropout.

Participant A2: I have noticed that the more students pass, the more they can retain their funding and the more the rate of dropouts is reduced.

Participant C1: Regarding the possible changes that I have noticed, the success rate of my students in those particular modules that have been tutored has improved drastically with fewer failures.

Participant D1: A reduction in the dropout rate is also an indication of students' success and employability outside the university or the Department of Education.

The above participants believe that the rate at which students drop out of the university had reduced due to tutorial sessions. This is also evident in their academic performance (Dockery, 2012). One of the participants who was a lecturer in the university said that the reduction in student drop out has also saved the funders/sponsors of some students a certain percentage of money that would have been spent on students who kept failing some specific modules. This indicates that the intervention of tutors through the office of the Centre for Teaching and Learning (CTL) was helpful. These statements also affirm a reduction in the failure rate because of the availability and support system of CTL through SI in the university. In other words, there has been a high number of students who had decided to stay back because of the SI support through tutors (Rumberger, 2001). This intervention has given the university and other institutions of higher learning a higher percentage of students who graduate each year.

Participant C1: As a tutor, success is when the pass rate has improved when compared to those students who do not attend tutorials.

Although this study does not compare the pass rate of students who attended tutorials to those who did not, there is a considerable difference between the two as attested by participant $\mathrm{C} 1$. At the same time, it is obvious that students who attended tutorial sessions improved academically (Skoglund, Wall \& Kiene, 2018). 


\section{Conclusion and Recommendations}

The finding, however, confirmed that the increment in students' achievement through $\mathrm{SI}$ is shown to be a success in the university and globally, both in academics and other areas. Hence, increment in students' achievement, retention of students and increased graduation output are additional advantages of why SI should be given priority in universities. SI enhances students' academic performance generally and has been proven to be effective when compared to those who attend tutorials and those who do not. This study analysed the two possible successes suggested for implementing SI in universities; the reduction of students' dropout rate and the increase of students' pass rate. The researcher agrees that the success of SI through tutorial sessions has shown to be helpful. Many students were said to have performed beyond the average level in their academics, students who had thought of giving up on their careers due to university challenges got assistance from SI to finish, and students who were below average level were also enhanced to distinction level. Students who were appointed as tutors had gained more experience both as tutors and students, their confidence enhanced, communication skills improved and increased student achievement output.

Based on the above findings, this study recommends that students, especially first-year students, be given more attention in their academics and other necessary support. Also, since first-year students are transiting to a new life in their academics, things like academic support system platform (SI, blackboard etc.) will be strange to them. This study also revealed that the number of students who graduate yearly has increased due to SI intervention. Lastly, this study also recommends that the university needs to motivate first-year students to see reasons why they have to attend tutorial sessions.

\section{References}

Adebola, O.O. (2020). The use of supplemental instruction in university classrooms as a strategy to enhance the academic performance of first-year students. Universal Journal of Educational Research, (8)11B, 6289-6296.

https://doi.org/10.13189/ujer.2020.082268

Adebola, O.O., Tsotetsi, C.T \& Omodan, B.I. (2020). Enhancing students' academic performance in the university system: The perspective of supplemental instruction. International Journal of Learning, Teaching and Educational Research, 19(5), 217-230. https://doi.org/10.26803/ijlter.19.5.13

Bertolini, K. Stremmel, A. \& Thorngren, J. (2016). Student achievement factors. Handbook, South Dakota University College of Education and Human Sciences Department of Teaching, Learning and Leadership. file:///C:/Users/bolab/Downloads/StudentAchievementFactorsBertoliniERIC.pdf/.

Braun, V. \& Clarke, V. (2006) Using thematic analysis in psychology. Qualitative Research in Psychology, 3(2), 77-101, http://dx.doi.org/10.1191/1478088706qp063oa

Budiharso, T. \& Tarman, B. (2020). Improving Quality Education through Better Working Conditions of Academic Institutes. Journal of Ethnic and Cultural Studies, 7(1), 99-115. http://dx.doi.org/10.29333/ejecs/306

Dana, J., Dawes, R., \& Peterson., N. (2013). Belief in the unstructured interview: The persistence of an illusion. Judgment and Decision Making, 8(5), 512-520. 
Dockery, D., J. (2012). School dropout indicators, trends, and interventions for school counsellors. Journal of School Counselling, 10(12), 4-23.

Double, K.S., McGrane, J.A., \& Hopfenbeck, T.H. (2020). The impact of peer assessment on academic performance: A meta-analysis of (quasi) experimental studies. Educational Psychology Review, 2020(32), 482-509 https://doi.org/10.1007/s10648-019-09510-3.

Fluke, S., O'Connor, A., Ho, N., \& Peterson, R. L. (2014). Academic support, strategy brief. Lincoln, NE: Student engagement project, University of Nebraska-Lincoln and the Nebraska Department of Education. http://k12engagement.unl.edu/academicsupports.

Goomas, D.T. (2014). The impact of supplemental instruction: Results from an urban community college. Community College Journal of Research and Practice, 38(12), 1180-1184.

Hermann, Z. (2010). A tanárok hatása a tanulói kompetenciák fejlődésére. Zárótanulmány [The effect of teachers on the development of student competences. Final study]. Budapest: MTA Közgazdaságtudományi Intézet. Retrieved from http://www.econ.core.hu/kutatas/edu/produktumok/tt.html

Holloway, I., \& Todres, L. (2003). The status of method: flexibility, consistency and coherence. Qualitative research, 3(3), 345-357.

Jugder, N. 2016. Global connectedness in higher education: student voices on the value of cross cultural learning dialogue. Studies in Higher Education, 41 (11), 2011-2027.

Kapur, R. (2018). Factors influencing the students' academic performance in secondary schools in India. Factors influencing the students' academic performance in secondary schools in India, 1, 25.

Kopish, M., \& Marques, W. (2020). Leveraging technology to promote global citizenship in teacher education in the United States and Brazil. Research in Social Sciences and Technology, 5(1), 45-69. https://doi.org/10.46303/ressat.05.01.3.

Malm, J., Bryngfors, L., \& Fredriksson, J. (2018). Impact of supplemental instruction on dropout and graduation rates: An example from 5-year engineering programs. Journal of Peer Learning, 11(1), 76-88.

Manalo, E., Marshall, J. \& Fraser, C. (2010). Student learning support programmes that demonstrate tangible impact on retention, pass rates and completion. Available at https://files.eric.ed.gov/fulltext/ED516139.pdf

Mbah, B. A. (2015). Effects of Prior Knowledge of Topics and the Instructional Objectives on Students' Achievement in Literature-in-English. Journal of Education and Practice, 6(20), 31-34.

Moodley, P. \& Singh, R. J. (2015). Addressing Student Dropout Rates at South African Universities. Alternation Special Edition, 17, 91 - 115.

Muray, M. (2014). Factors affecting graduation and student dropout rates at the University of KwaZulu-Natal. South African Journal of Science, 110(11), 1-6.

Narad, A., \& Abdullah, B. (2016). Academic performance of senior secondary school students: Influence of parental encouragement and school environment. Rupkatha Journal on Interdisciplinary Studies in Humanities, 8(2), 12-19.

Omodan, B. I., \& Ige, O. A. (2021). Sustaining collaborative learning among university students in the wake of COVID-19: The perspective of online community project. International 
Journal of Learning, Teaching and Educational Research, 20(1), 356-379.

https://doi.org/10.26803/ijlter.20.1.20

Rumberger, R.W. (2001). Why students drop out of school and what can be done. Available at https://escholarship.org/content/qt58p2c3wp/qt58p2c3wp.pdf.

Saleem, M., Adeeb, M., Hafeez, S., Siddique, A.R. \& Qasim, A. (2018). Academic support and academic achievement of university students: Mediating role of academic stress. Journal of Research and Reviews in Social Sciences Pakistan, 1, 72-81.

Skoglund, K., Wall, T.J. \& Kiene, D. (2018). Impact of supplemental instruction participation on college freshman retention. Learning Assistance Review, 23(1), 115-135.

Sukrajh, V. (2018). The use of peer teaching to promote active learning amongst senior medical students. Doctoral dissertation, Stellenbosch: Stellenbosch University.

Széll, K. (2013). Factors Determining Student Achievement. Hungarian Educational Research Journal, 3(3), 55-66. Available at https://core.ac.uk/download/pdf/161052542.pdf

Wilmot, J., \& Telang, N. K. (2017). Assessment of supplemental instruction programming on first-year academic success. In Conference proceedings of American Society of Engineering Education, Annual conference Columbus, Ohio.

Yasin, A. S., \& Dzulkifli, M. A. (2010). The relationship between social support and psychological problems among students. International Journal of Business and Social Science, 1(3), 110-116. 